\title{
Effective Ce-based catalysts deposition on ceramic open cell foams
}

\author{
Riccardo Balzarotti $^{\mathrm{a}, *}$, Laura Fratalocchi ${ }^{\mathrm{a}}$, Saverio Latorrata ${ }^{\mathrm{b}}$, Elisabetta Finocchio ${ }^{\mathrm{c}}$ and Cinzia \\ Cristiani $^{\text {b }}$
}

a Politecnico di Milano, Dipartimento di Energia, Via Lambruschini 4, 20156, Milano, Italy

b Politecnico di Milano, Dipartimento di Chimica, Materiali e Ingegneria Chimica “G. Natta”, Piazza Leonardo da Vinci 32, 20133

Milano, Italy

c Università di Genova, Dipartimento di Ingegneria Civile, Chimica e Ambientale, Via all'Opera Pia 15, 16145 Genova

\footnotetext{
* Corresponding author

E-mail: riccardo.balzarotti@polimi.it

Phone: +390223998654

Fax: +390223993280
}

\begin{abstract}
In this work, ceramic powder dispersion was achieved by using a glycerol/water solution as dispersion medium and polyvinyl alcohol as binder and rheology modifier. Five different powders were dispersed and they were deposited onto open cell ceramic foams: the bare carrier (i.e. cerium oxide) and four catalytically active powders (i.e. nickel, cobalt, iron and copper oxides supported on ceria). Catalysts powders have been extensively characterized and were demonstrated to be suitable samples candidates of model catalysts for the deposition onto open-cell foams. Rheological properties were found to be related to the dispersed powder, thus directly affecting washcoat load. Multiple depositions were performed by means of dip-coating on 20, 30 and 40 PPI Y-stabilized $\mathrm{ZrO}_{2}$ open cell foams. Depending on formulation and foam pore density, coating loads in the 6-30 \% wt. range were obtained. Washcoat layers were found to be quite homogeneous and well adherent therefore suitable for catalytic applications, such as for instance the methane steam reforming synthesis for Ni-based catalysts.
\end{abstract}

Keywords: catalysis; deposition; coating; rheology; open-cell foams 


\section{Introduction}

In recent years, structured catalysts and reactors for process intensification have gained increasingly importance due to their interesting properties [1]. In particular, open cell foams have been tested for several heterogeneous processes [2]. Indeed, high rates can be achieved in terms of fluid/solid mass/heat transfer inside the reactor, thanks to the complex geometry of support channels. Moreover, open-cell foams are characterized by high interface area and high porosity; this produces low pressure drop and it ensures high energy efficiency if compared to traditional packed bed systems [3-5]. Among others, syngas production in steam reforming and Fisher-Tropsch processes were improved by employing sponges as catalyst support $[6,7]$

In order to maximize active phase performance inside of the reactor, many ceramic materials such as alumina, silica and titania have been investigated as high surface area supports [8-12]. At the same time, $\mathrm{CeO}_{2}$-based oxides were intensively studied as active phase carriers due to their peculiar characteristics [1316]. As a matter of fact, cerium oxide has been widely investigated as carrier due to its oxygen storage capacity (OSC), redox properties and high catalytic performances in different reforming processes for hydrogen production [17]. In Fischer-Tropsch synthesis, cerium based catalysts have been investigated for their selectivity towards lower molecular weight olefins, thanks to ceria high surface affinity with both $\mathrm{CO}$ and $\mathrm{H}_{2}[18]$.

A variety of metallic ions have been proposed as active phase for the most different chemical processes. High costs associated to noble metals have induced researchers to deeply investigate other solutions with the employment of transition metals. In several cases, cobalt [19,20] and nickel [21,22] demonstrated to be a good alternative to noble metals, while iron has been widely used in Fischer-Tropsch synthesis [23]. Copper has been investigated for water gas sift (WGS) reactions [24,25] as well as for low temperature CO oxidation [26].

In case of structured reactors, the bare morphological substrate is usually washcoated with a thin catalytically active layer, which is deposited by a washcoating process [27,28]. Washcoating usually requires support pretreatment; then, catalyst deposition can be performed by using different techniques. Among others, dipcoating technique is widely recognized as the best compromise between cost, effectiveness and practicality [29]. Washcoat load, thickness and adhesion depend primarily on the physical-chemical properties of the powders and on the rheological behavior of the slurry [30-32].

Slurry rheological properties may be affected by several parameters that can be mainly related to powder (i.e. nature of the solid and powder particle dimensions), dispersion medium (i.e. powder loading, dispersant concentration and presence of viscosity modulator) and to environmental conditions (i.e. temperature) [29]. In case of high surface area catalysts, one of the easiest ways to obtain a stable solid particles dispersion is to perform powder surface charging by using acidic solutions [6,32-34]. Unfortunately, this process cannot be used with non-chargeable low surface area powders or with acid-sensitive surfaces. In these cases, an alternative dispersion method needs to be used. The use of high molecular weight organic compound to be used as dispersants is usually the best way to achieve particles dispersion and stabilization [35-37]. 
In this work, an acid-free formulation was used in order to obtain stable oxide dispersions. Slurries were produced by using hydroxyl-based organic compounds as dispersants via steric-like mechanism [38,39].

These slurries were used to deposit thin catalyst layers on structured supports. Commercial cerium oxide (3 $\mathrm{m}^{2} \cdot \mathrm{g}^{-1}$ ) was used as carrier, while nickel, cobalt, iron and copper were selected as representative active phases. Model catalytic powder was obtained by using the dry-impregnation route: the carrier was impregnated with the active phase via repeated immersion-drying cycles. Aqueous solutions containing the active metals $(\mathrm{Ni}, \mathrm{Co}, \mathrm{Fe}$ or $\mathrm{Cu})$ nitrate precursors were used in order to reach about $7 \%$ wt. of metal referred to the $\mathrm{CeO}_{2}$ carrier. This quantity is determined dividing the mass of precursor by the sum of carrier and precursor itself. The obtained catalyst powders have been extensively characterized by FT-IR, UV Vis., SEM-EDX and XRD techniques.

Depositions were performed by means of dip-coating technique. Ceramic open cell foams with different pore per inch (PPI) densities (i.e. 20, 30 and 40 PPI) were used as structured supports. Results were evaluated in terms of coating load and adhesion performance, by means of gravimetric analysis and adhesion test in ultrasound, respectively. The final goal was to understand how catalytic powders may affect slurry rheology and coating deposition on supports of different porosities.

\section{Experimental}

\subsection{Catalyst preparation}

Cerium oxide (CeLS, Sigma-Aldrich), a commercially available low surface area oxide, was used as carrier for catalyst production via incipient wetness impregnation [6]. $\mathrm{Ni}\left(\mathrm{NO}_{3}\right)_{2} \cdot 6 \mathrm{H}_{2} \mathrm{O}(98.5 \%), \mathrm{Co}\left(\mathrm{NO}_{3}\right)_{2} \cdot 6 \mathrm{H}_{2} \mathrm{O}$ (98\%), $\mathrm{Fe}\left(\mathrm{NO}_{3}\right)_{3} \cdot 9 \mathrm{H}_{2} \mathrm{O}(97 \%)$ and $\mathrm{Cu}\left(\mathrm{NO}_{3}\right)_{2} \cdot 3 \mathrm{H}_{2} \mathrm{O}(98 \%)$ all supplied by Sigma Aldrich were used as active phase precursors. The selected amount of nitrates were dissolved in distilled water under magnetic stirring at room temperature and dropped on the carrier. A final metal load of $7 \%$ wt. was considered (referred to the sum of carrier and metallic active phase). After impregnation procedure, powders were dried overnight at $120{ }^{\circ} \mathrm{C}$ first and then heated in air for $10 \mathrm{~h}, 2{ }^{\circ} \mathrm{C} \cdot \mathrm{min}^{-1}$ both for heating and cooling ramp. $\mathrm{Co}, \mathrm{Fe}$ and $\mathrm{Cu}$ based sample (CoCeLS, FeCeLS and CuCeLS in the following) were calcinated at $400{ }^{\circ} \mathrm{C}$, while Ni-based sample (NiCeLS in the following) at $800{ }^{\circ} \mathrm{C}$. These temperatures were selected as close as those reported for industrial applications $[20,40]$.

\subsection{Catalyst characterization}

Catalyst powders crystalline structure was investigated by means of X-ray diffraction. A Bruker D8 Advance diffractometer with graphite monochromated $\mathrm{Cu}-\mathrm{K} \alpha$ radiation was used $\left(10-80^{\circ} 2 \theta\right.$ range, $40 \mathrm{kV}$ and $40 \mathrm{~mA}$, 
step scan $0.02^{\circ} 2 \theta$, time $1 \mathrm{~s} \cdot \mathrm{step}^{-1}$ ). Crystallite dimensions were evaluated from line broadening of the reflections (FWHM, calculated by Topas) using the Scherrer equation [41].

Catalysts powders, diluted in KBr pellets, were also analyzed by FT IR spectroscopy, by means of a FT IR Instrument Nexus ThermoNicolet (OMNIC software, 100 scans, DTGS detector, background air). Diffuse Reflectance UV-Vis. NIR measurements have been performed on pure powders, in air, in a Jasco V570 Spectrometer equipped with an integrating sphere.

ICP-MS measurements were performed to quantify active phase content by using an X Series II instrument by Thermo Fischer. Samples reducibility was investigated by means of $\mathrm{H}_{2}$-TPR analyses by using a Micromeritics Thermoquest TPDRO1100 instrument, according to a procedure reported in literature [42].

Powders particle size was evaluated by using a CILAS 1180 laser granulometer (Compagnie Industrielle des Lasers, Orleans, France), while physical characterization of BET surface area and pore volume was performed by using a Tristar 3000 device (Micromeritics, Norcross, GA, USA). $\mathrm{N}_{2}$ physisorprion measurements were carried out after heating at $150{ }^{\circ} \mathrm{C}$ overnight, under vacuum. An Autopore IV instrument (Micromeritics, Norcross, GA, USA) was used for Hg intrusion.

Structured support surface was characterized by using an optical microscope (SZ-CTV microscope, Olympus, Tokio, Japan).

SEM-EDX measurements were performed using a scanning electron microscope (Evo 50 EP, Zeiss,

Oberkochen, Germany) coupled with an X-ray spectrometer (Inca Energy 200-Pentaflex, Oxford Instruments, Abingdon, UK).

Coating thickness was assessed by means of fracture analysis. In order to avoid coating detachment during mechanical operations, samples were included in a commercially available epoxy resin (Mecaprex by Presi). After curing, foams were divided into two parts; internal faces were finely polished and characterized by optical microscope.

\subsection{Washcoating}

Powder dispersion was achieved by using an acid-free formulation based on water and organic compounds [38]. In a typical experiment, glycerol $(\mathrm{G})$ (87\% wt. water solution, Sigma-Aldrich) and distilled water $(\mathrm{H})$ were used as dispersant and liquid medium, respectively. Polyvinyl alcohol (PVA) (Mowiol 88-8, SigmaAldrich) was added to the formulation to act as rheology modifier, as well as binding agent during the transition between wet coating and solid washcoat layer. Liquid medium was produced by using the three components with 1.9, 1.8 and 0.07 weight ratios with respect to powder and it was thus labeled as HGP.

In this work, slurries have been obtained according to a procedure developed by the Authors and detailed elsewhere reported in literature $[34,38,43]$. Typically, PVA was dissolved water at $85{ }^{\circ} \mathrm{C}$ under magnetic stirring. Then, glycerol was added and the dispersion liquid medium HGP was thus obtained. HPG, powders and grinding bodies $\left(\mathrm{ZrO}_{2}\right.$ spheres, $1 \mathrm{~cm}$ diameter) were mixed into a polyethylene jars to be ball milled for 
24 hours at $50 \mathrm{rpm}$. After the milling process, the slurries underwent a sonication pre-treatment for 30 minutes to reduce foaming.

Slurries rheological properties were evaluated by using a DSR 200 device (Rheometrics, New Castle, DE, USA). Parallel disc plates (diameter $40 \mathrm{~mm}$ ) were used for analysis and viscosity was evaluated in the $1-10^{3}$ $\mathrm{s}^{-1}$ shear rate range.

20, 30 and 40 PPI (pore per inch) yttria-stabilized zirconia alumina (YZA) open cell foams (Selee Company, Hendersonville, NC, USA) were used as structured support for washcoat deposition (Fig. 1) via dip-coating technique $[38,43]$.
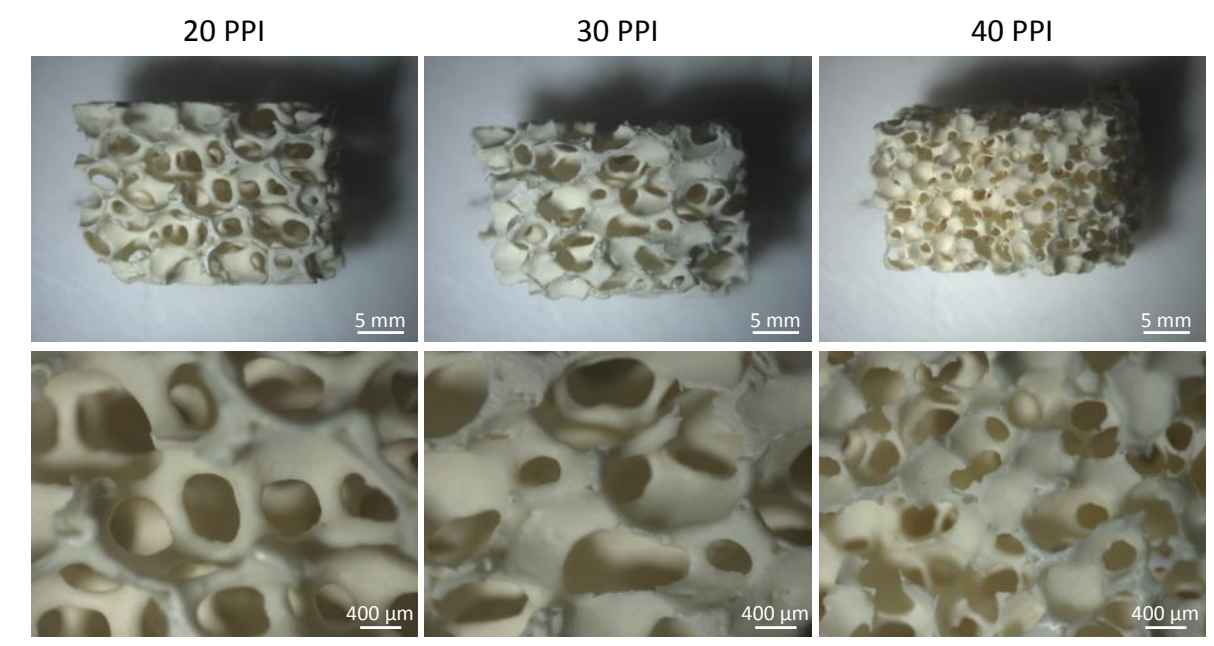

Fig. 1 - Optical microscope images of bare Selee open cell ceramic foams at different magnifications

Parallelepiped shaped samples of squared section (length $1.5 \mathrm{~cm}$ and section $1 \mathrm{~cm}$ ) were used after a cleaning pre-treatment with ultrasound bath for 30 minutes in acetone. For both dipping and withdrawing steps, coater speed was set at $13 \mathrm{~cm} \cdot \mathrm{min}^{-1}$; excess coating was gently removed by air blowing. After coating process, a flash drying heat treatment was performed for 6 minutes at $350{ }^{\circ} \mathrm{C}$, in a sealed oven. Single and multiple depositions were experienced, and, in case of multiple depositions, an intermediate flash drying between two subsequent depositions was performed. Flash dried washcoated foams were finally calcinated for $10 \mathrm{~h}$ at $400{ }^{\circ} \mathrm{C}\left(\mathrm{Co}, \mathrm{Fe}\right.$ and $\mathrm{Cu}$ based samples) and $800{ }^{\circ} \mathrm{C}(\mathrm{Ni})$, with heating and cooling rates of 2 ${ }^{\circ} \mathrm{C} \cdot \min ^{-1}$.

Gravimetric analysis was used in order to evaluate washcoat deposition by the difference of the coated and bare foams. In order to determine washcoat adhesion on support, adhesion tests were performed according to [6] where after 30 minutes of sonication in petroleum ether bath weight loss was determined by gravimetric analysis before and after the test.

Washcoated supports morphology was analyzed by using a scanning electronic microscope (Stereoscan 360, Cambridge Instruments).

\section{Results and discussion}

\subsection{Catalyst characterization}


All powder samples, i.e. CeLS, NiCeLS, CoCeLS, FeCeLS and CuCeLS ( 7 wt.\% Ni, Co, Fe and $\mathrm{Cu}$ on metal base), were prepared according to Section 2.1; results of physical and chemical characterization tests are reported in Tab. 1.

Tab. 1- Active phase content and morphological properties of the powders

\begin{tabular}{|c|c|c|c|c|c|c|}
\hline \multirow{2}{*}{ Sample name } & \multirow{2}{*}{$\begin{array}{l}\text { Nominal Metal } \\
\text { content (\% wt.) }\end{array}$} & \multicolumn{3}{|c|}{ Measured active phase content (\% wt.) } & \multirow{2}{*}{$\begin{array}{l}\text { Surface area } \\
{\left[\mathrm{m}^{2} \cdot \mathrm{g}^{-1}\right]}\end{array}$} & \multirow{2}{*}{$\begin{array}{c}\text { Active phase } \\
\text { crystal size }[\mathrm{nm}]\end{array}$} \\
\hline & & ICP & EDX & TPR & & \\
\hline CeLS & - & - & - & - & $2 \pm 1$ & - \\
\hline NiCeLS & \multirow{4}{*}{7} & 6.0 & $7.8( \pm 1.0)$ & 7.6 & $3 \pm 1$ & 44 \\
\hline CoCeLS & & 6.3 & $9.9( \pm 1.5)$ & 7.2 & $3 \pm 1$ & 37 \\
\hline FeCeLS & & 5.9 & $7.6( \pm 0.7)$ & 6.5 & $3 \pm 1$ & - \\
\hline CuCeLS & & 6.2 & $5.0( \pm 0.2)$ & 7.9 & $2 \pm 1$ & 31 \\
\hline
\end{tabular}

For all samples, ICP measurements showed results in the $6 \%$ wt. range, which is in fairly good accordance with nominal metal content, given the difficulty to dissolve metal oxide active phase during solution process. In order to get further indications on active phase amount deposited onto the carrier, SEM-EDX analyses were carried out. Results are in reasonable agreement with the theoretical active phase content (7\% wt.) in Ni-based sample $(7.8 \pm 1.0 \%$ wt.), while a slightly higher value $(9.9 \pm 1.5 \%$ wt. $)$ was found for cobalt; values of $7.6 \pm 0.7 \%$ wt. and $5.0 \pm 0.2 \%$ wt. were found for FeCeLS and CuCeLS, respectively (Tab. 1).

The discrepancy between theoretical and actual metal content can be related with the low surface area $(2$ $\mathrm{m}^{2} \cdot \mathrm{g}^{-1}$ ) of the morphological carrier, which does not allow a homogeneous dispersion of the active phase. Indeed, low surface area also means small pores volume and large pores dimensions. According to this picture, it is quite hard to identify the total pores filling during impregnation, as required in case of incipient wetness procedure. Moreover, a low surface area carrier is, in principle, characterized by a limited number of surface interacting species (e.g. hydroxide groups), which are unable to control the formation of large metal aggregates. Therefore, the metal content variability observed for all the sample could be due to concurrent unavoidable errors in both EDX measurements and preparation procedures.

Additional quantification of metal content was obtained by $\mathrm{H}_{2}$-TPR (a detailed discussion of reduction behavior is reported in the following); the moles of metallic active phase in each sample were calculated from the moles of $\mathrm{H}_{2}$-consumed during the analyses according to the specific reduction reaction. As a result, an active phase content of 7.6, 7.2, 7.9 and $6.5 \%$ wt. were found for NiCeLS, CoCeLS, CuCeLS and FeCeLS samples, respectively. These results are in reasonable accordance with both the results obtained by ICP and EDX analyses.

XRD powders characterization is reported in Fig. 2. The offset in the figure is the magnification of the spectral region where the main reflections of the active phase are detected. 


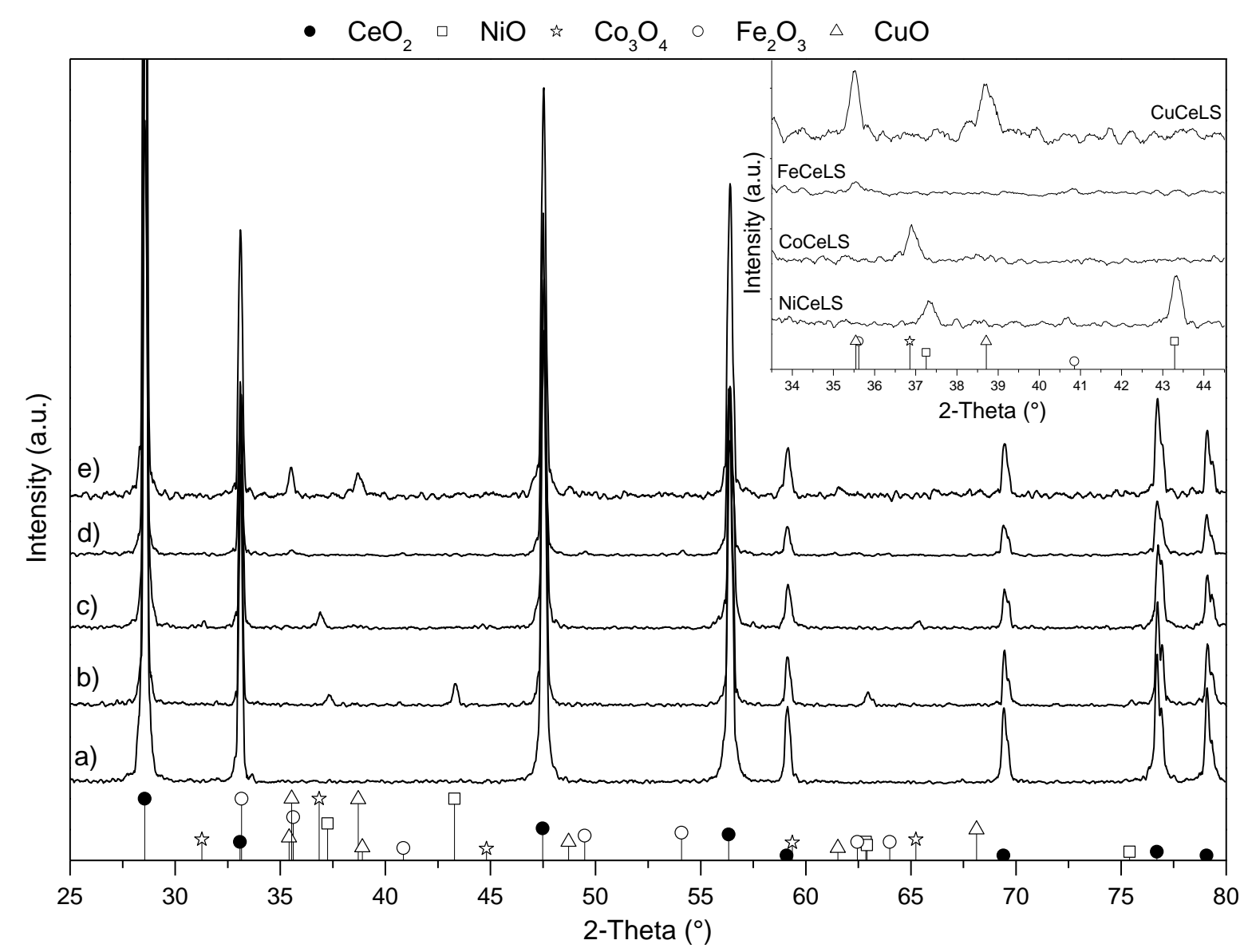

Fig. 2- XRD analysis of Ce-supported catalysts powder: CeLS (a), NiCeLS (b), CoCeLS (c), FeCeLS (d) and CuCeLS (e). (Offset magnification of the spectral range in the region 34-44 $2 \theta^{\circ}$ )

The presence of cerium oxide (PDF 034-0394) is observed as well as active phases reflections are evident. In most cases, thanks to the absence of peaks overlapping, $\mathrm{Ni}$, $\mathrm{Co}$ and $\mathrm{Cu}$ metal oxides can be clearly identified: nickel is detected by the reflections at 29 values of $37.2^{\circ}, 43.2^{\circ}$ and $63^{\circ}$, corresponding to $\mathrm{NiO}$ (PDF 044-1159) (Fig. 2-b), cobalt is identified by the reflections at 29 values of $36.9^{\circ}$ and $65.4^{\circ}$, corresponding to $\mathrm{Co}_{3} \mathrm{O}_{4}$ (PDF 042-1460) (Fig. 2-c) and copper by reflections at $2 \vartheta$ values of $35.6^{\circ}, 38.8^{\circ}$ and $61^{\circ}$ corresponding to $\mathrm{CuO}$ (PDF 048-1548) (Fig. 2-e).

On the contrary, the identification of iron oxide is more complex and uncertain, as its main reflections are hidden by the $33.1^{\circ}$ reflection of cerium oxide. Moreover, $\mathrm{Fe}_{2} \mathrm{O}_{3}$ (PDF 033-0664) and $\mathrm{Fe}_{3} \mathrm{O}_{4}$ (PDF 019-0629) main peaks are very close: the former has most intense reflections at 33.1 and 35.6, while the latter has the two most intense peaks at 30.1 and 35.5. In the diffractogram, only a small and broad peak is barely evident near $35.5^{\circ} 29$; considering the very low relative intensity, a certain characterization is not possible. In addition to the main peak overlapping, issues related to iron identification may be also due to the type of radiation used $(\mathrm{Cu}-\mathrm{K} \alpha)$, which is not well suited for iron identification due to its intensity. Moreover, both the active phase low concentration and the iron oxide dispersion/low crystallinity may concur in making iron oxide identification difficult.

Crystallite dimensions were calculated for all samples from the evaluation of the FWHM according to Scherrer equation. Analysis was performed on reflections centered at 29 values equal to $37.2^{\circ}$ and $43.2^{\circ}$ for 
nickel oxide and at $36.9^{\circ}$ for cobalt oxide, while $35.6^{\circ}$ and $38.8^{\circ}$ reflections were used for copper oxide. Active phase crystallite dimensions of the three samples are almost comparable and they are characterized by average values of about 30 to $40 \mathrm{~nm}$. Large crystallites dimensions are still consistent with the low surface area of both carrier and final materials (Tab. 1). No calculation was possible in case of Fe-based samples for the reason discussed above.

Spectroscopic characterization results are in agreement with data discussed above. All the FT-IR skeletal spectra of these samples (Fig. 3-a) show the main absorptions assigned to ceria structure in the low frequency region of the spectrum, i.e. $460 \mathrm{~cm}^{-1}$, ca, tailing to higher frequencies. The position of this maximum is slightly shifted by the presence of other metal oxides, whose typical absorptions are extensively overlapped with ceria ones in the low frequency spectral region, therefore difficult to evidence. For instance: pure Ni oxide shows a main typical absorption around $460 \mathrm{~cm}^{-1}$ with shoulder at higher frequency which has been assigned to the IR active mode of the NiO rock-salt structure, splitting in two TO and LO components. A small shift in the wavenumber in comparison with literature reports can be explained by different shape and particle size [44]. $\mathrm{Cu}$ oxide has been reported to show IR features below $600 \mathrm{~cm}^{-1}$, thus extensively overlapped with ceria component absorptions. Also Fe-based oxides, i.e. pure $\mathrm{Fe}_{2} \mathrm{O}_{3}$, usually show broad absorptions around 545 and $445 \mathrm{~cm}^{-1}$ [45] barely detectable as high frequency shoulders of the main absorption in the FeCe sample spectrum (470, tailing to $720 \mathrm{~cm}^{-1}$ ). Only cobalt oxide features can be clearly detected at 663 and $565 \mathrm{~cm}^{-1}$, characterizing $\mathrm{Co}_{3} \mathrm{O}_{4}$ particles [46]. The detection of different oxide species is even more evident from UV-Vis NIR spectra, where features due to metallic oxides are consistent with those reported for the corresponding pure oxides (Fig. 3-b). The main feature below $400 \mathrm{~nm}$ detectable in all the spectra is a split absorption with maxima at 270 and $350 \mathrm{~nm}$, mainly due to the ceria component of the support. Escribano et al. assigned the former maximum to allowed $\mathrm{O}_{2}^{-} \rightarrow \mathrm{Ce}^{4+}$ charge transfer transitions, whose intensity and position depends on particle size [47].
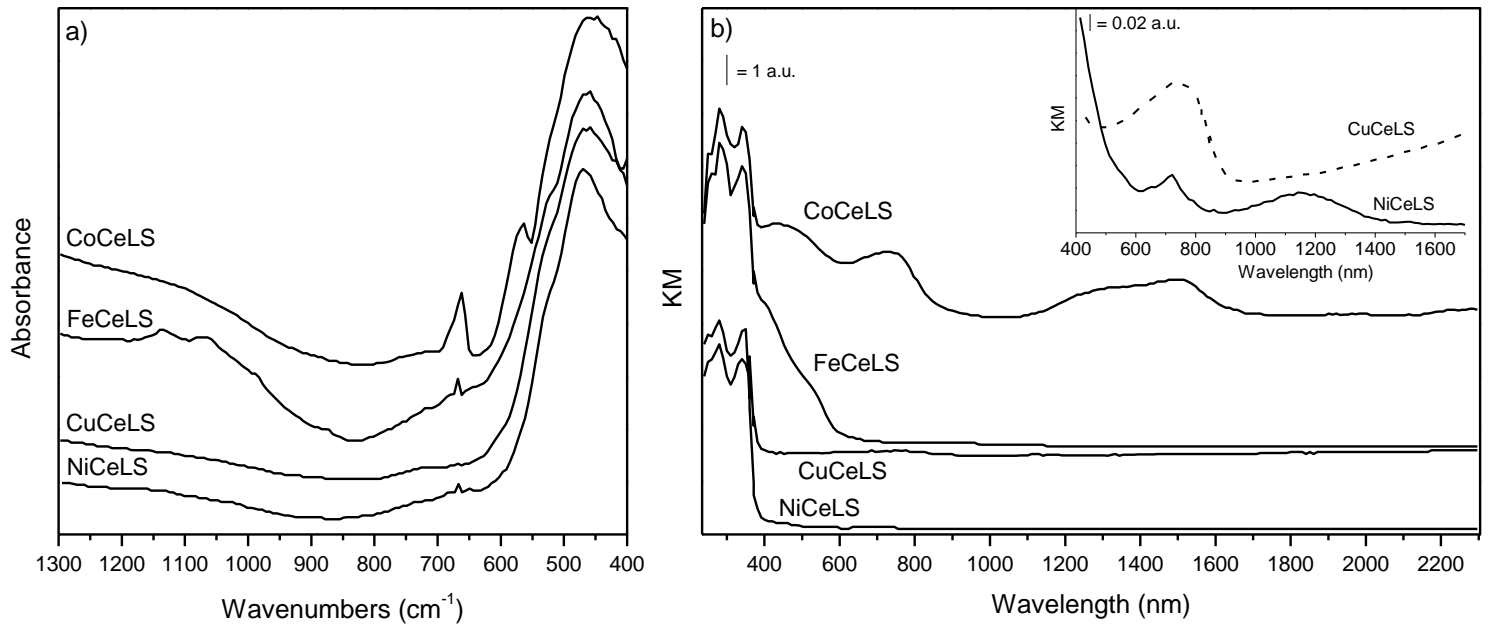

Fig. 3- FT-IR skeletal spectra (a) and Uv-Vis. NIR spectra (b) of the catalyst powders

$\mathrm{CuO}$ particles give rise to a very weak band between 700 and $800 \mathrm{~nm}$, according to the lowest metal content obtained in this sample, and assigned to fundamental electronic transition of $\mathrm{Cu}^{2+}$ ions in $\mathrm{CuO}$ small particles, slightly shifted in comparison to bulk $\mathrm{CuO}$ samples by the small particle size $[48,49]$. Broad bands 
due to $\mathrm{Co}_{3} \mathrm{O}_{4}$ particles are detected at 435 and $726 \mathrm{~cm}^{-1}, 1325$ and $1500 \mathrm{~cm}^{-1}$, characterizing Co ions in different coordination state in the CoCeLS sample [46], whereas Ni oxide is characterized by bands at 410 (shoulder), 645 (weak), $720 \mathrm{~nm}$ and $1140 \mathrm{~nm}$. These bands have been reported as diagnostic of massive $\mathrm{NiO}$ particles by Garbarino et al. (Fig. 3-b, inset) [44]. Impregnation with Fe-salts results in a broad and complex band tailing in the visible-NIR range, with some maxima around 400, 525, 650 and $860 \mathrm{~nm}$, which have been previously related to charge transfer absorption involving $\mathrm{Fe}^{3+}$ ions [47].

In order to have an overview of catalysts reduction behavior, TPR analyses were performed on catalytic materials; results are reported in Fig. 4.

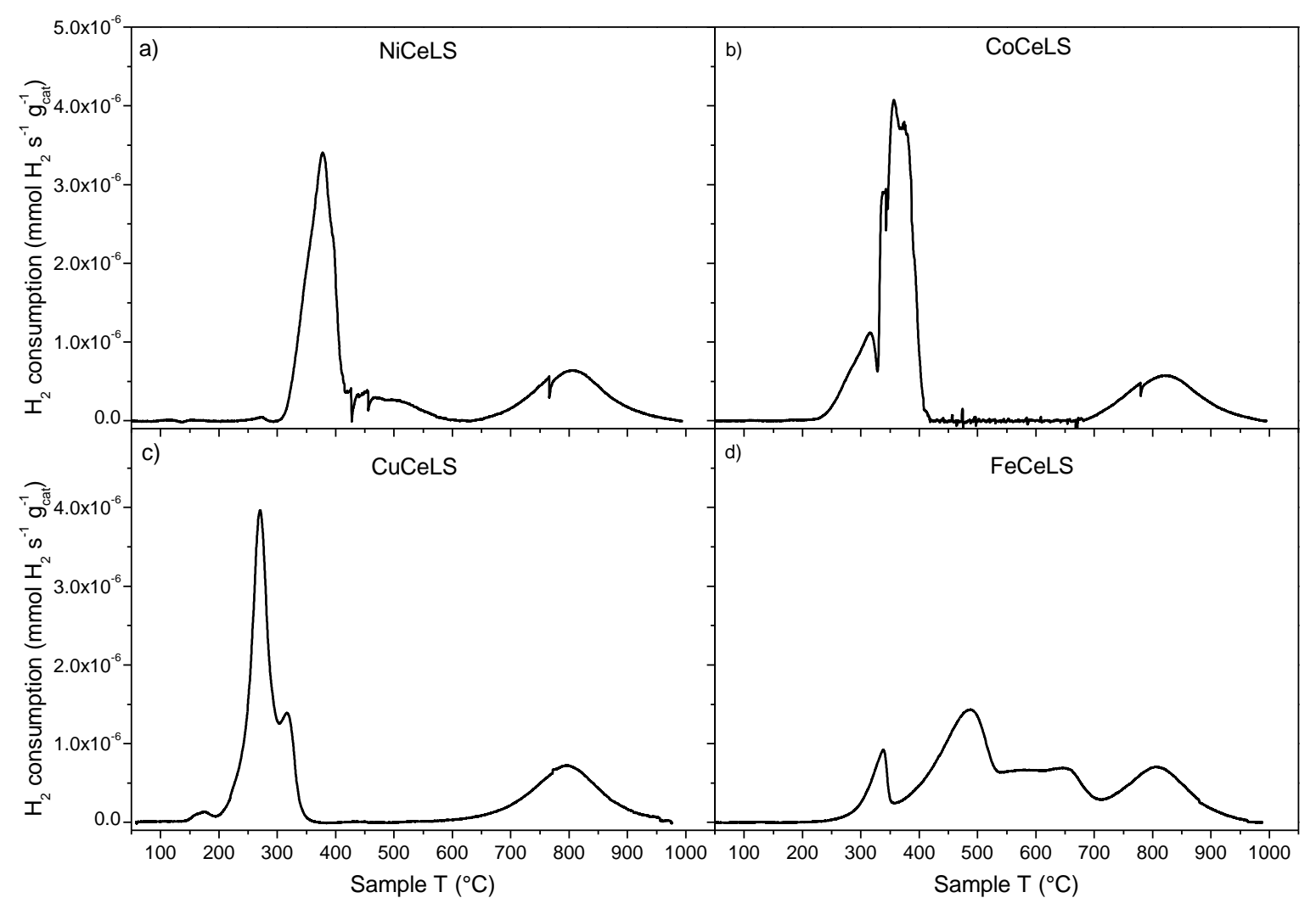

Fig. $4-\mathrm{H}_{2}$ TPR of the catalysts: NiCeLS (a), CoCeLS (b), CuCeLS (c) and FeCeLS (d)

With the exception of FeCeLS sample, all the TPR profiles show two regions of hydrogen consumption, namely the ranges $150-600{ }^{\circ} \mathrm{C}$ (LT) and $600-1000{ }^{\circ} \mathrm{C}(\mathrm{HT})$, which can be associated with the reduction of the active phase and ceria carrier, respectively. $\mathrm{CeO}_{2}$ reduction is reported to occur by a two-steps process, namely the low temperature reduction of surface layers of $\mathrm{Ce}^{4+}$ and, then, the reduction of the inner $\mathrm{Ce}^{4+}$ layer (bulk reduction) at higher temperatures. With low surface area ceria, only one peak due to bulk $\mathrm{Ce}^{4+}$ reduction is observed, as reduction at low temperatures is negligible [50].

The reduction of NiCeLS shows three peaks in the LT range (Fig. 4-a); according to literature, the low temperature peak $\left(269^{\circ} \mathrm{C}\right)$ can be attributed to traces quantities of $\mathrm{Ni}^{2+}$ that replaced $\mathrm{Ce}^{4+}$ into the lattice of $\mathrm{CeO}_{2}$ [51]. The second and third reduction peaks are centered at $376{ }^{\circ} \mathrm{C}$ and $510{ }^{\circ} \mathrm{C}$ and they can be attributed, according to literature, to the reduction of strongly interactive $\mathrm{NiO}$ species with $\mathrm{CeO}_{2}$ support and to bulk $\mathrm{NiO}$ reduction, respectively [52]. 
The $\mathrm{H}_{2}$-TPR profile of CoCeLS sample (Fig. 4-b) presents two hydrogen uptakes at $315{ }^{\circ} \mathrm{C}$ and $356{ }^{\circ} \mathrm{C}$; according to literature [53,54], this indicates that the reduction occurs in two steps: $\mathrm{Co}_{3} \mathrm{O}_{4} \rightarrow \mathrm{CoO} \rightarrow \mathrm{Co}^{0}$. This is in accordance with the identification of the $\mathrm{Co}_{3} \mathrm{O}_{4}$ species carried out by XRD and IR analysis. The $\mathrm{H}_{2}$-TPR of CuCeLS sample (Fig. 4-c) points two main peaks, centered at $173{ }^{\circ} \mathrm{C}$ and $270{ }^{\circ} \mathrm{C}$, respectively. According to literature, the peak at lower temperature can be attributed to the reduction of highly dispersed copper oxide strongly interacting with ceria surface, while the higher temperature peak can be identified with the reduction of "bulk-like" $\mathrm{CuO}$ particles less interacting with $\mathrm{CeO}_{2}[55,56]$. The interpretation of FeCeLS data is affected by the partial convolution of the peaks related to the iron active phase with the $\mathrm{CeO}_{2}$ reduction peak centered at $806{ }^{\circ} \mathrm{C}$. Despite the complexity, three peaks can be identified, corresponding to three reduction steps at $338^{\circ} \mathrm{C}\left(\mathrm{Fe}_{2} \mathrm{O}_{3} \rightarrow \mathrm{Fe}_{3} \mathrm{O}_{4}\right), 487^{\circ} \mathrm{C}\left(\mathrm{Fe}_{3} \mathrm{O}_{4} \rightarrow \mathrm{FeO}\right)$ and $653{ }^{\circ} \mathrm{C}\left(\mathrm{FeO} \rightarrow \mathrm{Fe}^{0}\right)$ [57].

In order to coat the open cell foams supports powders were dispersed in the HGP (water, glycerol and PVA) liquid medium, according to the procedure reported in Section 2.3. Results in terms of slurry rheological properties are shown in Fig. 5, where the curve of the carrier is reported for sake of comparison.

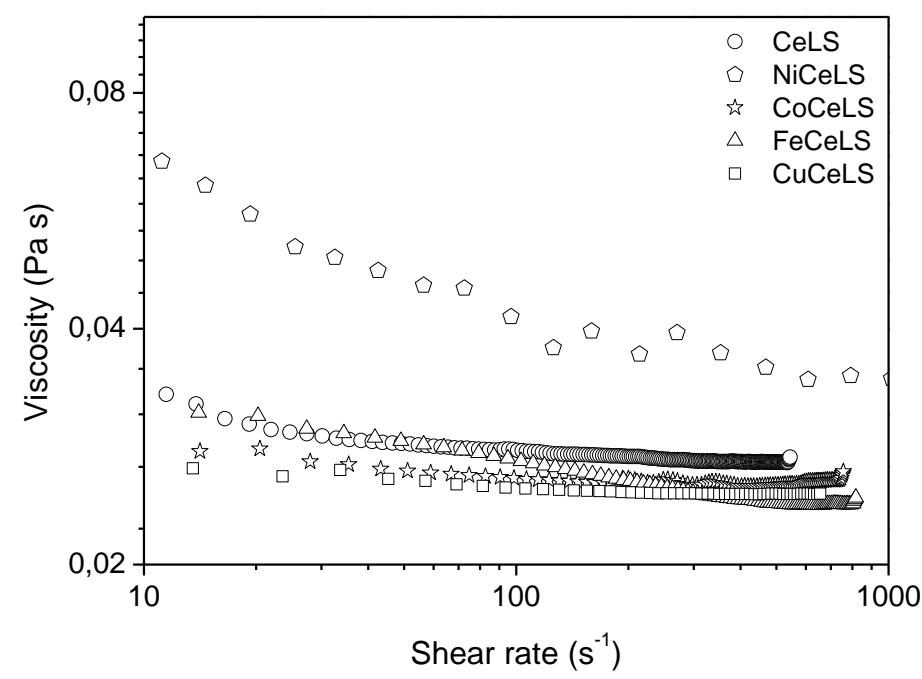

Fig. 5- Rheological curves of CeLS, NiCeLS, CoCeLS, FeCeLS and CuCeLS in HGP liquid medium after 24 h of ball milling

Already at visual inspection (Fig. 5), different behaviors both in terms of rheology and absolute viscosity are evident between NiCeLs and all the other samples, possibly due to the nature of the metal ion. The NiCeLS powder displays a stronger shear thinning rheological behavior in comparison with others, almost Newtonian. Additionally, NiCeLS slurry showed the highest viscosity. Significant rheological properties values for the evaluation of the slurries behavior are summarized in Tab. 2, where the slope of the flow curve and the viscosity at fixed shear are reported. Both were considered in the range of shear 10-100 $\mathrm{s}^{-1}$, which is typical of dip-coating applications. The higher the value (in modulus) of the slope, the higher the nonNewtonian behavior.

Tab. 2- Samples rheological properties

\begin{tabular}{ccc}
\hline \hline Slurry name & Viscosity at $10 \mathrm{~s}^{-1}[\mathrm{~Pa} \cdot \mathrm{s}]$ & $\begin{array}{c}\text { Slope across shear } \\
\text { rate } 10-100 \mathrm{~s}^{-1}\end{array}$ \\
\hline CeLS & 0.034 & 0.042
\end{tabular}




\begin{tabular}{lll} 
NiCeLS & 0.067 & 0.205 \\
CoCeLS & 0.028 & 0.060 \\
FeCeLS & 0.032 & 0.073 \\
CuCeLS & 0.026 & 0.029 \\
\hline
\end{tabular}

The close similarity of $\mathrm{Co}-, \mathrm{Fe}-$ and $\mathrm{Cu}$-based materials is manifest: viscosities in the range $0.02-0.03 \mathrm{~Pa} \cdot \mathrm{S}$ are measured accompanied by very similar Newtonian behavior, which also resemble the behavior of the carrier. The case of Ni-containing slurry is different, as it is rather viscous with a shear thinning behavior.

In order to explain this peculiar behavior, an attempt to correlate powders physic-chemical properties and rheological ones was made. As already reported in a previous paper [43], the rheological behavior can be rationalized by taking into account the presence and the nature of the active phase. Indeed, the presence of a metal oxide, although at the surface, changes the density of the material and, therefore the number of powder particles in a fixed weight of powder is different. This should result in a different volumetric fraction of particles in a fixed volume of liquid. Accordingly, the dependence of viscosity on powders density was calculated. Results at two different shear rates are reported in Fig. 6-a.
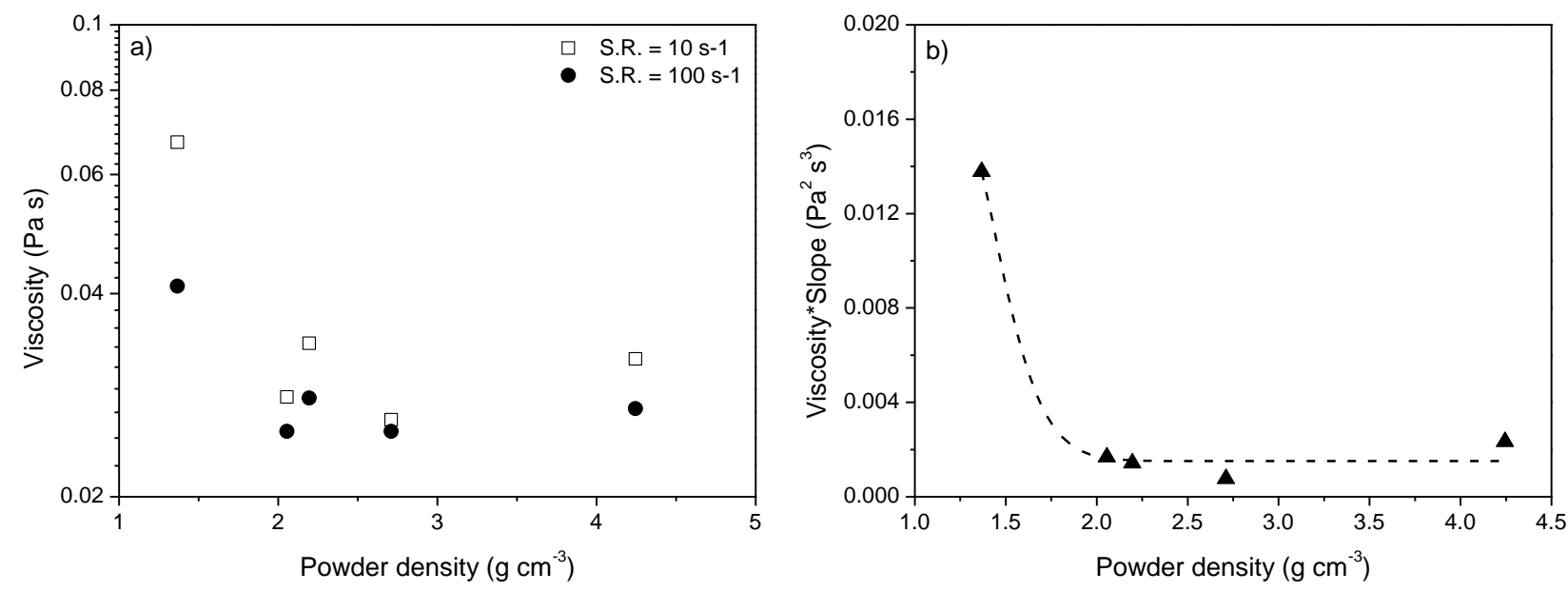

Fig. 6 - Slurry viscosity dependence on powder density (a) and on viscosity·load product (b)

Real powder density was calculated from material bulk density as the weighted sum of the bulk densities of the carrier and the active phase, when present [43]. Moreover in the calculation also the material porosity, determined by means of mercury intrusion analysis, was taken into account. Viscosity decreases with powder density, at both shear rate values, and it seems not to be dependent on the chemical nature of the powders constituents.

\subsection{Slurry deposition}

\subsubsection{Multiple depositions on 20 PPI open cell ceramic foams}

20 PPI (Pores Per Inch) ceramic open cell foams were used for washcoat deposition, according to procedure reported in Section 2.3. In Fig. 7, results in terms of washcoat load upon calcination are reported as a 
function of viscosity (reported at shear rate equal to $10 \mathrm{~s}^{-1}$, Fig. 7-a) and slurry rheological behavior (Fig. 7b); the latter refers to flow curves slope values that are listed in Tab. 2.
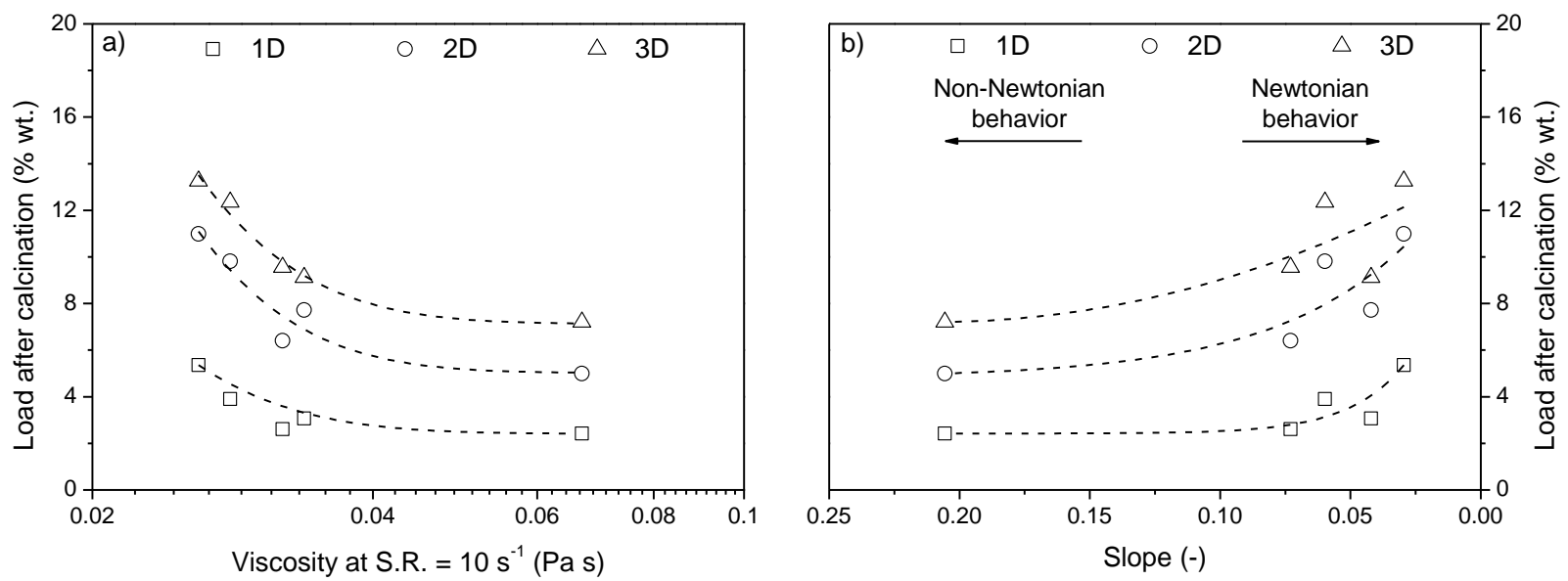

Fig. 7 - Load after calcination as a function of viscosity (a) and rheological behavior (b) after multiple deposition on 20 PPI foams

Results show (Fig. 7-a) a decrease of washcoat load with the increase of viscosity, at any dipping number. Therefore a higher viscosity should lead to a lower load, which is in contrast with the theory of the dipcoating process. On the contrary, a load increase was associated with the increase of the Newtonian behavior of the slurry (Fig. 7-b); therefore, both viscosity and nature of the fluid are responsible for the macroscopic effects on load. Despite of larger absolute viscosity, non-Newtonian slurries resulted in lower coating loads as is the case of the highly viscous non-Newtonian NiCeLS slurry, which presented the lowest washcoat loads (7.2\% wt. after three depositions). The observed difference in coating load for samples of very close viscosity values strengthen this picture: it seems that there is a stronger dependence on rheological behavior than on the sole absolute viscosity (Tab. 2, Fig. 7). The effect of Newtonianity could be explained taking into account the movement of the fluid inside the foam pores during the wet film deposition on support surface. Indeed, Newtonian behavior was found to be the best for coating application onto ceramic foams [38]. Coating adhesion of all the samples was tested by means of ultrasound stress test in petroleum ether. Results are shown in Fig. 8. 


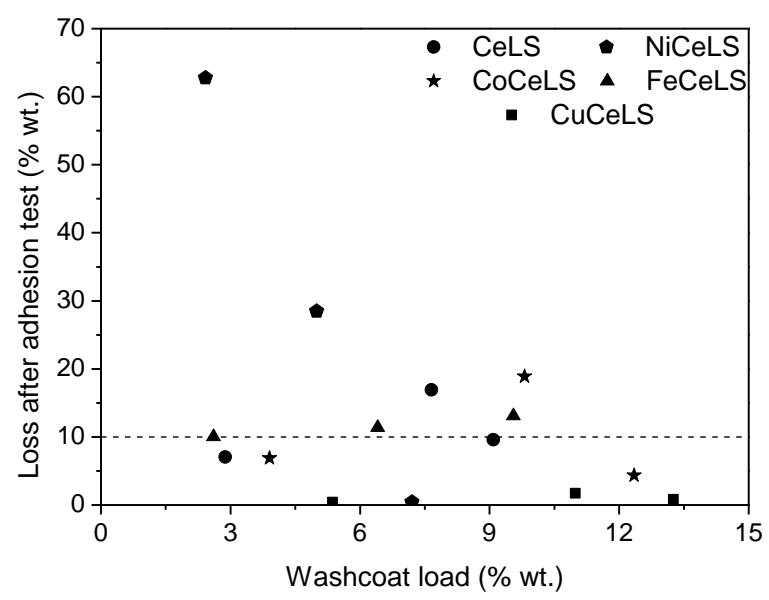

Fig. 8- Washcoat weight loss after adhesion test: dependence on coating load.

Results are difficult to be rationalized. Averagely, weight losses are within 5 and $20 \%$ wt., but apparently no direct relation with composition or load can be inferred. It has to be underlined that these data can be affected by errors due to the brittleness of the ceramic supports that can be partially broken during manipulation, and particularly during the adhesion test. Moreover, it should be taken into account that calcination process for NiCeLS sample was carried out at higher temperature $\left(800{ }^{\circ} \mathrm{C}\right)$ with respect to the other samples $\left(400{ }^{\circ} \mathrm{C}\right)$; this may affect washcoat adhesion, as an increase in calcination temperature was reported to improve washcoat adhesion results [32]. However, this point still deserves for further investigation. Moreover, it has to considered that the ultrasound adhesion stress tests possibly induces largely higher physical stresses than those experienced by the sample inside a reactor in presence of reaction fluids.

\subsubsection{Effect of pore density}

In order to assess load dependence on foam pore density, several tests were performed by deposition on 30 and 40 PPI ceramic sponges. Results obtained for all slurries are reported in Fig. 9, as a function of support pores density.

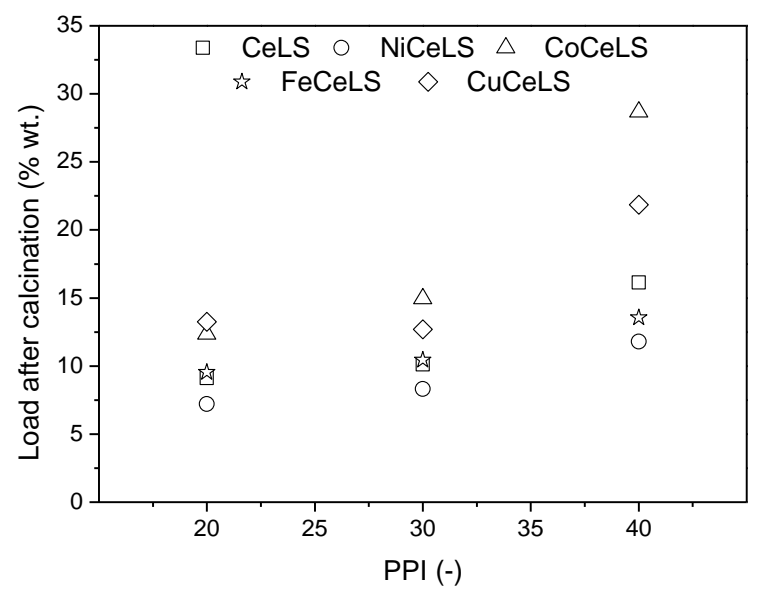

Fig. 9- Load after calcination after 3 dippings: dependence on open-cell foam porosity 
For all slurries, a load increase with the increase of pore density was found. This phenomenon may be due to the fact that support surface area per unit volume increases with porosity, thus, a higher amount of coating could be in principle deposited on the foam.

Once more, all the samples were evaluated from the adhesion point of view. Results of ultrasound test in petroleum ether are shown in Fig. 10; 20 PPI adhesion test results are reported again, for sake of comparison.

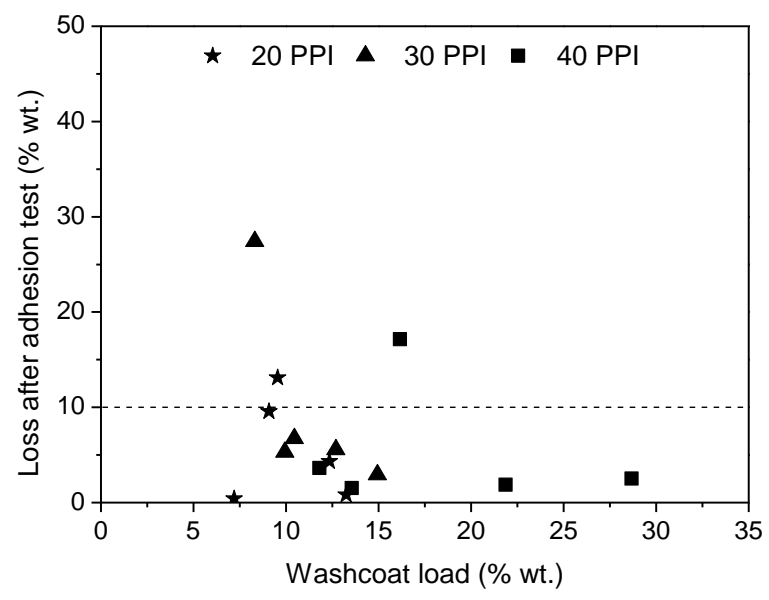

Fig. 10 - Weight loss dependence on washcoat load after 3 dippings: support porosity influence

With the exception of three samples that lost up to $25 \%$ wt., all the others presented losses lower than $10 \%$ wt. As introduced before, it has to-be considered that the ultrasound adhesion stress tests possibly induce largely higher physical stresses than those experienced by the sample inside a reactor in presence of reaction fluids. In the literature, weight loss up to $10 \%$ wt. is reported as satisfactory for washcoat adhesion [6]. Accordingly, samples adhesion found in our case can be considered averagely acceptable. Deposited layers homogeneity was evaluated by means of SEM measurements (Fig. 11). For sake of brevity, only results obtained for Ni and Co active phases have been reported. 

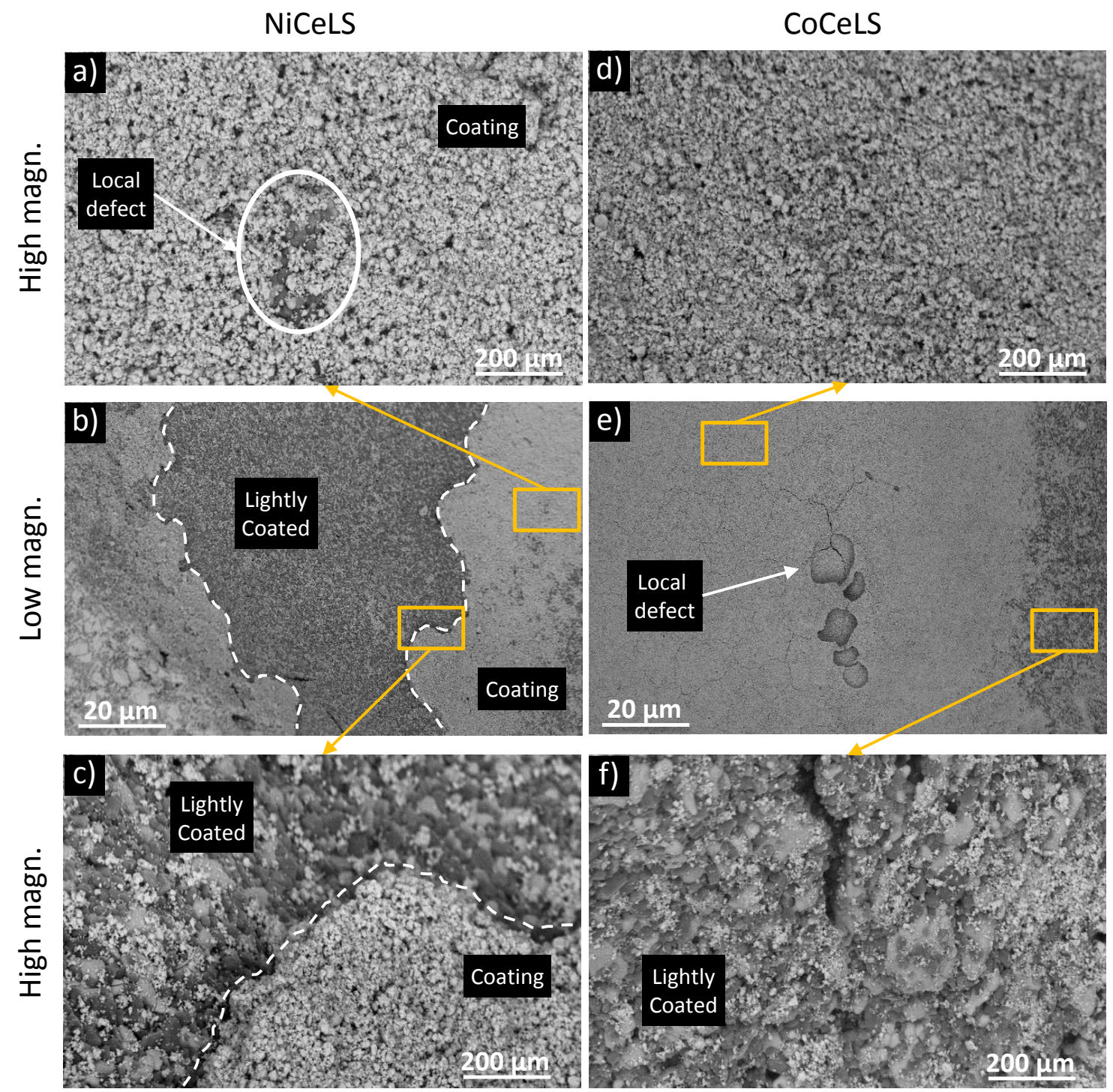

Fig. 11- SEM analysis of NiCeLS (a, b and c) and CoCeLS (d, e and f) at different magnifications (back scattering)

The coating layers appeared homogeneous, even though some local defects are present, especially in the very sharp part of the foams struts, which are difficult to be coated (Fig. 11-b and e). At larger magnification (Fig. 11 -a and d), the texture of a uniform coating can be appreciated and only local and very limited areas are affected by small defects. In any case, non-homogeneous or less covered areas (Fig. 11-c and f) are just limited to local points. Moreover, some local defects, similar to bubbles, can be noticed in Fig. 11-e. Their presence may be ascribed to a non-optimal local decomposition of the organic additives during flash drying thermal treatments. These particular defects could be responsible in some samples for the observed bad adhesion, therefore coating detachment.

In order to assess washcoat thickness, a fracture analysis was also performed on the three-times dipped samples by means of optical microscope. Results are shown in Fig. 12. 


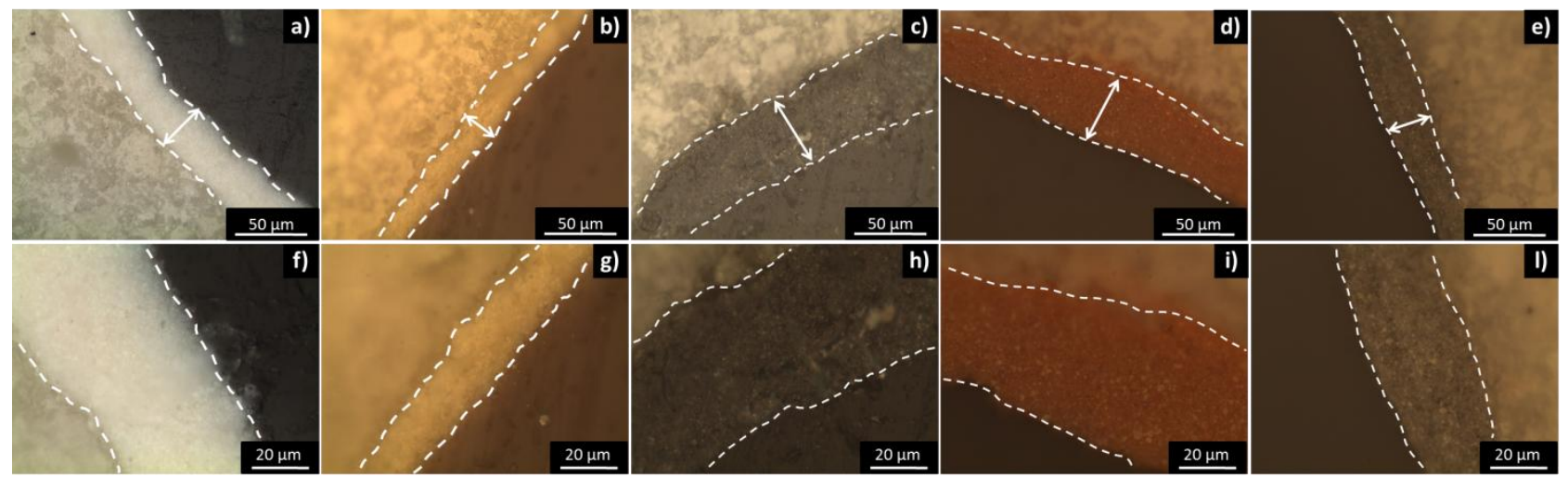

Fig. 12- Washcoat evaluation by fracture analysis on samples CeLS (a, f), NiCeLS (b, g), CoCeLS (c, h), FeCeLS (d, i) and $\mathrm{CuCeLS}(\mathrm{e}, \mathrm{l})$ at 500X (top) and 1000X (bottom) magnifications

In all cases, the presence of a homogeneous washcoat layer is evident. Measured layer thickness is variable from sample to sample: 20, 45 and $51 \mu \mathrm{m}$ values were found for NiCeLS, CeLS and CoCeLS samples, respectively, while values of $40 \mu \mathrm{m}$ and $28 \mu \mathrm{m}$ were found for FeCeLS and CuCeLS layers. These values are in good accordance with the behavior of the increasing load trend previously reported. In addition to that, coated layers appeared to be well adherent to support surface, as no defects and dishomogeneities are present at the washcoat/foam interface. Good coating compactness and no detachment of coating layers were observable, which are apparently in contrast with the not completely satisfactory results of adhesion tests. Therefore, once more, the strong severity of the test can be inferred to explain high coating loss. However, although possibly misleading, such a test is useful to evaluate deposited layers quality at least as merit ranking.

\section{Conclusions}

Characterization data of powdered catalysts suggest the formation of oxide active phase particles loosely interacting with cerium oxide component in the catalyst formulations.

The dispersion medium based on water, glycerol and polyvinyl alcohol evidenced good performance in producing slurry suitable for open cell foam activation. Moreover, the mutual influence of viscosity and rheological behavior on final washcoat load was pointed out, allowing a better understanding of washcoat load management.

Washcoat load was found to increase with the increase of pore density, probably due to the fact that support surface area per unit volume increases with porosity and, thus, a higher amount of coating could be in principle deposited on the foam.

Washcoat thickness analysis confirmed the presence of homogeneous and well adhered layers, whose thickness is in accordance with the trends found for washcoat load.

Activity tests on Ni-based catalyst in the steam reforming process are forecast to further evaluate the consistency of the preparation method. 


\section{References}

[1] E. Tronconi, G. Groppi, Preface, Catal. Today. 147 (2009) S1. doi:10.1016/j.cattod.2009.07.085.

[2] E. Bianchi, T. Heidig, C.G. Visconti, G. Groppi, H. Freund, E. Tronconi, An appraisal of the heat transfer properties of metallic open-cell foams for strongly exo-/endo-thermic catalytic processes in tubular reactors, Chem. Eng. J. 198-199 (2012) 512-528. doi:10.1016/j.cej.2012.05.045.

[3] L. Giani, G. Groppi, E. Tronconi, Mass-transfer characterization of metallic foams as supports for structured catalysts, Ind. Eng. Chem. Res. 44 (2005) 4993-5002. doi:10.1021/ie0490886.

[4] J.T. Richardson, Y. Peng, D. Remue, Properties of ceramic foam catalyst supports: Pressure drop, Appl. Catal. A Gen. 204 (2000) 19-32. doi:10.1016/S0926-860X(00)00508-1.

[5] T.J. Lu, H. a. Stone, M.F. Ashby, Heat transfer in open-cell metal foams, Acta Mater. 46 (1998) 3619-3635. doi:10.1016/S1359-6454(98)00031-7.

[6] C. Cristiani, E. Finocchio, S. Latorrata, C.G. Visconti, E. Bianchi, E. Tronconi, G. Groppi, P. Pollesel, Activation of metallic open-cell foams via washcoat deposition of $\mathrm{Ni} / \mathrm{MgAl}_{2} \mathrm{O}_{4}$ catalysts for steam reforming reaction, Catal. Today. 197 (2012) 256-264. doi:10.1016/j.cattod.2012.09.003.

[7] M. Lacroix, L. Dreibine, B. De Tymowski, F. Vigneron, D. Edouard, D. Bégin, P. Nguyen, C. Pham, S. Savin-Poncet, F. Luck, M.J. Ledoux, C. Pham-Huu, Silicon carbide foam composite containing cobalt as a highly selective and re-usable Fischer-Tropsch synthesis catalyst, Appl. Catal. A Gen. 397 (2011) 62-72. doi:10.1016/j.apcata.2011.02.012.

[8] S. Bagheri, N. Muhd Julkapli, S. Bee Abd Hamid, Titanium Dioxide as a Catalyst Support in Heterogeneous Catalysis, Sci. World J. 2014 (2014) 727496. doi:10.1155/2014/727496.

[9] R. Huirache-Acuña, R. Nava, C. Peza-Ledesma, J. Lara-Romero, G. Alonso-Núez, B. Pawelec, E. Rivera-Muñoz, SBA-15 Mesoporous Silica as Catalytic Support for Hydrodesulfurization CatalystsReview, Materials (Basel). 6 (2013) 4139-4167. doi:10.3390/ma6094139.

[10] M. Trueba, S.P. Trasatti, $\gamma$-alumina as a support for catalysts: A review of fundamental aspects, Eur. J. Inorg. Chem. (2005) 3393-3403. doi:10.1002/ejic.200500348.

[11] G. Busca, Acid Catalysts in Industrial Hydrocarbon Chemistry, Chem. Rev. 107 (2007) 5366-5410. doi:10.1021/cr068042e.

[12] G. Busca, Structural, Surface, and Catalytic Properties of Aluminas, Adv. Catal. 57 (2014) 319-404. doi:10.1016/B978-0-12-800127-1.00003-5.

[13] S. Hosokawa, M. Taniguchi, K. Utani, H. Kanai, S. Imamura, Affinity order among noble metals and $\mathrm{CeO}_{2}$, Appl. Catal. A Gen. 289 (2005) 115-120. doi:10.1016/j.apcata.2005.04.048.

[14] I. Maupin, J. Mijoin, J. Barbier, N. Bion, T. Belin, P. Magnoux, Improved oxygen storage capacity on $\mathrm{CeO}_{2}$ /zeolite hybrid catalysts. Application to VOCs catalytic combustion, Catal. Today. 176 (2011) 103-109. doi:10.1016/j.cattod.2011.02.003.

[15] A. Vita, G. Cristiano, C. Italiano, L. Pino, S. Specchia, Syngas production by methane oxy-steam reforming on $\mathrm{Me} / \mathrm{CeO}_{2}(\mathrm{Me}=\mathrm{Rh}, \mathrm{Pt}, \mathrm{Ni})$ catalyst lined on cordierite monoliths, Appl. Catal. B Environ. 162 (2015) 551-563. doi:10.1016/j.apcatb.2014.07.028.

[16] C.G. Maciel, T.D.F. Silva, M.I. Hirooka, M.N. Belgacem, J.M. Assaf, Effect of nature of ceria support in $\mathrm{CuO} / \mathrm{CeO}_{2}$ catalyst for PROX-CO reaction, Fuel. 97 (2012) 245-252. doi:10.1016/j.fuel.2012.02.004. 
[17] L. Pino, A. Vita, M. Laganà, V. Recupero, Hydrogen from biogas: Catalytic tri-reforming process with Ni/LaCeO mixed oxides, Appl. Catal. B Environ. 148-149 (2014) 91-105.

doi:10.1016/j.apcatb.2013.10.043.

[18] M. Arsalanfar, A.A. Mirzaei, H.R. Bozorgzadeh, H. Atashi, S. Shahriari, A. Pourdolat, Structural characteristics of supported cobalt-cerium oxide catalysts used in Fischer-Tropsch synthesis, J. Nat. Gas Sci. Eng. 9 (2012) 119-129. doi:10.1016/j.jngse.2012.05.015.

[19] E. Iglesia, Design, synthesis, and use of cobalt-based Fischer-Tropsch synthesis catalysts, Appl. Catal. A Gen. 161 (1997) 59-78. doi:10.1016/S0926-860X(97)00186-5.

[20] A.Y. Khodakov, W. Chu, P. Fongarland, Advances in the development of novel cobalt FischerTropsch catalysts for synthesis of long-chain hydrocarbons and clean fuels, Chem. Rev. 107 (2007) 1692-1744. doi:10.1021/cr050972v.

[21] C. Wang, S. Friedrich, T.R. Younkin, R.T. Li, R.H. Grubbs, D.A. Bansleben, M.W. Day, Neutral Nickel(II)-Based Catalysts for Ethylene Polymerization, Organometallics. 17 (1998) 3149-3151. doi:10.1021/OM980176Y.

[22] Y. Li, D. Li, G. Wang, Methane decomposition to $\mathrm{CO}_{\mathrm{x}}$-free hydrogen and nano-carbon material on group 8-10 base metal catalysts: A review, Catal. Today. 162 (2011) 1-48.

doi:10.1016/j.cattod.2010.12.042.

[23] B.H. Davis, Fischer-Tropsch Synthesis: Reaction mechanisms for iron catalysts, Catal. Today. 141 (2009) 25-33. doi:10.1016/j.cattod.2008.03.005.

[24] P. Guo, L. Chen, Q. Yang, M. Qiao, H. Li, H. Li, H. Xu, K. Fan, Cu/ZnO/Al ${ }_{2} \mathrm{O}_{3}$ water-gas shift catalysts for practical fuel cell applications: the performance in shut-down/start-up operation, Int. J. Hydrogen Energy. 34 (2009) 2361-2368. doi:10.1016/j.jhydene.2008.12.081.

[25] S. Pradhan, A.S. Reddy, R.N. Devi, S. Chilukuri, Copper-based catalysts for water gas shift reaction: Influence of support on their catalytic activity, Catal. Today. 141 (2009) 72-76. doi:10.1016/j.cattod.2008.06.026.

[26] U.R. Pillai, S. Deevi, Room temperature oxidation of carbon monoxide over copper oxide catalyst, Appl. Catal. B Environ. 64 (2006) 146-151. doi:10.1016/j.apcatb.2005.11.005.

[27] M. Campanati, G. Fornasari, A. Vaccari, Fundamentals in the preparation of heterogeneous catalysts, Catal. Today. 77 (2003) 299-314. doi:10.1016/S0920-5861(02)00375-9.

[28] V. Meille, Review on methods to deposit catalysts on structured surfaces, Appl. Catal. A Gen. 315 (2006) 1-17. doi:10.1016/j.apcata.2006.08.031.

[29] P. Avila, M. Montes, E.E. Miró, Monolithic reactors for environmental applications: A review on preparation technologies, Chem. Eng. J. 109 (2005) 11-36. doi:10.1016/j.cej.2005.02.025.

[30] C.J. Brinker, G.W. Scherer, Sol-gel science: the physics and chemistry of sol-gel processing, Academic Press, 1990.

[31] S. Middleman, Fundamentals of polymer processing, 1977.

[32] M. Valentini, G. Groppi, C. Cristiani, M. Levi, E. Tronconi, P. Forzatti, The deposition of $\gamma-\mathrm{Al}_{2} \mathrm{O}_{3}$ layers on ceramic and metallic supports for the preparation of structured catalysts, Catal. Today. 69 (2001) 307-314. doi:10.1016/S0920-5861(01)00383-2.

[33] C.G. Visconti, E. Tronconi, L. Lietti, G. Groppi, P. Forzatti, C. Cristiani, R. Zennaro, S. Rossini, An experimental investigation of Fischer-Tropsch synthesis over washcoated metallic structured supports, Appl. Catal. A Gen. 370 (2009) 93-101. doi:10.1016/j.apcata.2009.09.023.

[34] C. Cristiani, C.G. Visconti, E. Finocchio, P.G. Stampino, P. Forzatti, Towards the rationalization of 
the washcoating process conditions, Catal. Today. 147 (2009) 24-29.

doi:10.1016/j.cattod.2009.07.031.

[35] X.K. Phan, H. Bakhtiary-Davijany, R. Myrstad, P. Pfeifer, H.J. Venvik, A. Holmen, Preparation and performance of Cu-based monoliths for methanol synthesis, Appl. Catal. A Gen. 405 (2011) 1-7. doi:10.1016/j.apcata.2011.07.005.

[36] J.Y. Won, H.K. Jun, M.K. Jeon, S.I. Woo, Performance of microchannel reactor combined with combustor for methanol steam reforming, Catal. Today. 111 (2006) 158-163. doi:10.1016/j.cattod.2005.11.004.

[37] G. Germani, A. Stefanescu, Y. Schuurman, A.C. van Veen, Preparation and characterization of porous alumina-based catalyst coatings in microchannels, Chem. Eng. Sci. 62 (2007) 5084-5091. doi:10.1016/j.ces.2007.02.034.

[38] R. Balzarotti, C. Cristiani, S. Latorrata, A. Migliavacca, Washcoating of low surface area cerium oxide on complex geometry substrates, Part. Sci. Technol. 34 (2016) 184-193. doi:10.1080/02726351.2015.1058872.

[39] H. Zhang, W.J. Suszynski, K.V. Agrawal, M. Tsapatsis, S. Al Hashimi, L.F. Francis, Coating of open cell foams, Ind. Eng. Chem. Res. 51 (2012) 9250-9259. doi:10.1021/ie300266p.

[40] D. Sutton, B. Kelleher, J.R.H. Ross, Review of literature on catalysts for biomass gasification, Fuel Process. Technol. 73 (2001) 155-173. doi:10.1016/S0378-3820(01)00208-9.

[41] B.D. Cullity, Elements of X-Ray Diffraction, 3rd ed., Pearson, 2001.

[42] L. Fratalocchi, C.G. Visconti, L. Lietti, N. Fischer, M. Claeys, A promising preparation method for highly active cobalt based Fischer-Tropsch catalysts supported on stabilized $\mathrm{Al}_{2} \mathrm{O}_{3}$, Appl. Catal. A Gen. 556 (2018) 92-103. doi:10.1016/J.APCATA.2018.02.002.

[43] R. Balzarotti, M. Ciurlia, C. Cristiani, F. Paparella, Washcoat deposition of Ni- and Co-ZrO $\mathrm{Zn}_{2}$ low surface area powders onto ceramic open-cell foams: influence of slurry formulation and rheology, Catalysts. 5 (2015) 2271-2286. doi:10.3390/catal5042271.

[44] G. Garbarino, I. Valsamakis, P. Riani, G. Busca, On the consistency of results arising from different techniques concerning the nature of supported metal oxide (nano)particles. The case of $\mathrm{NiO} / \mathrm{Al}_{2} \mathrm{O}_{3}$, Catal. Commun. 51 (2014) 37-41. doi:10.1016/J.CATCOM.2014.03.018.

[45] M. Baldi, V.S. Escribano, J.M.G. Amores, F. Milella, G. Busca, Characterization of manganese and iron oxides as combustion catalysts for propane and propene, Appl. Catal. B Environ. 17 (1998) L175-L182. doi:10.1016/S0926-3373(98)00013-7.

[46] J. Gonzalez-Prior, J. Ignacio Gutierrez-Ortiz, R. Lopez-Fonseca, G. Busca, E. Finocchio, B. de Rivas, Oxidation of chlorinated alkanes over $\mathrm{Co}_{3} \mathrm{O}_{4} / \mathrm{SBA}-15$ catalysts. Structural characterization and reaction mechanism, Catal. Sci. Technol. 6 (2016) 5618-5630. doi:10.1039/c6cy00321d.

[47] V. Sánchez Escribano, E. Fernández López, M. Panizza, C. Resini, J.M. Gallardo Amores, G. Busca, Characterization of cubic ceria-zirconia powders by X-ray diffraction and vibrational and electronic spectroscopy, Solid State Sci. 5 (2003) 1369-1376. doi:10.1016/J.SOLIDSTATESCIENCES.2003.07.001.

[48] F. Boccuzzi, S. Coluccia, G. Martra, N. Ravasio, $\mathrm{Cu} / \mathrm{SiO}_{2}$ and $\mathrm{Cu} / \mathrm{SiO}_{2}-\mathrm{TiO}_{2}$ Catalysts: I. TEM, DR UV-Vis-NIR, and FTIR Characterisation, J. Catal. 184 (1999) 316-326. doi:10.1006/JCAT.1999.2428.

[49] S. Velu, K. Suzuki, M. Okazaki, M.P. Kapoor, T. Osaki, F. Ohashi, Oxidative Steam Reforming of Methanol over $\mathrm{CuZnAl}(\mathrm{Zr})-\mathrm{Oxide}$ Catalysts for the Selective Production of Hydrogen for Fuel Cells: Catalyst Characterization and Performance Evaluation, J. Catal. 194 (2000) 373-384. 
doi:10.1006/JCAT.2000.2940.

[50] A. Trovarelli, Structural and Oxygen Storage/Release Properties of $\mathrm{CeO}_{2}$-Based Solid Solutions, Comments Inorg. Chem. 20 (1999) 263-284. doi:10.1080/02603599908021446.

[51] S. Mahammadunnisa, P. Manoj Kumar Reddy, N. Lingaiah, C. Subrahmanyam, $\mathrm{NiO} / \mathrm{Ce}_{1-\mathrm{x}} \mathrm{Ni}_{\mathrm{x}} \mathrm{O}_{2-\delta}$ as an alternative to noble metal catalysts for CO oxidation, Catal. Sci. Technol. 3 (2013) 730-736. doi:10.1039/C2CY20641B.

[52] W. Zou, C. Ge, M. Lu, S. Wu, Y. Wang, J. Sun, Y. Pu, C. Tang, F. Gao, L. Dong, Engineering the $\mathrm{NiO} / \mathrm{CeO}_{2}$ interface to enhance the catalytic performance for $\mathrm{CO}$ oxidation, RSC Adv. 5 (2015) 98335-98343. doi:10.1039/C5RA20466F.

[53] S.M. de Lima, A.M. da Silva, L.O.O. da Costa, U.M. Graham, G. Jacobs, B.H. Davis, L. V. Mattos, F.B. Noronha, Study of catalyst deactivation and reaction mechanism of steam reforming, partial oxidation, and oxidative steam reforming of ethanol over $\mathrm{Co} / \mathrm{CeO}_{2}$ catalyst, J. Catal. 268 (2009) 268281. doi:10.1016/J.JCAT.2009.09.025.

[54] M. Kang, M.W. Song, C.H. Lee, Catalytic carbon monoxide oxidation over $\mathrm{CoO}_{\mathrm{x}} / \mathrm{CeO}_{2}$ composite catalysts, Appl. Catal. A Gen. 251 (2003) 143-156. doi:10.1016/S0926-860X(03)00324-7.

[55] P. Zhu, J. Li, Q. Huang, S. Yan, M. Liu, R. Zhou, High performance $\mathrm{CuO}-\mathrm{CeO}_{2}$ catalysts for selective oxidation of $\mathrm{CO}$ in excess hydrogen: Effect of hydrothermal preparation conditions, J. Nat. Gas Chem. 18 (2009) 346-353. doi:10.1016/S1003-9953(08)60119-X.

[56] G. Avgouropoulos, T. Ioannides, H. Matralis, Influence of the preparation method on the performance of $\mathrm{CuO}-\mathrm{CeO}_{2}$ catalysts for the selective oxidation of $\mathrm{CO}$, Appl. Catal. B Environ. 56 (2005) 87-93. doi:10.1016/J.APCATB.2004.07.017.

[57] A.S. Reddy, C.-Y. Chen, C.-C. Chen, S.-H. Chien, C.-J. Lin, K.-H. Lin, C.-L. Chen, S.-C. Chang, Synthesis and characterization of $\mathrm{Fe} / \mathrm{CeO}_{2}$ catalysts: Epoxidation of cyclohexene, J. Mol. Catal. A Chem. 318 (2010) 60-67. doi:10.1016/J.MOLCATA.2009.11.008. 